УДК $551.24+552.31: 550.4$

\title{
ОКИСЛИТЕЛЬНО-ВОССТАНОВИТЕЛЬНЫЙ ФОН В ЗЕМНОЙ КОРЕ СИХОТЭ-АЛИНЬСКОГО ОРОГЕННОГО ПОЯСА ПРИ КРИСТАЛЛИЗАЦИИ МАГМАТИТОВ МЕЛ-ПАЛЕОГЕНОВОГО ВОЗРАСТА: СВЯЗЬ С ГЕОДИНАМИКОЙ
}

\author{
Талтыкин Ю. В., Мищин Л. Ф., Коновалова Е. А. \\ ФГБУН Институт тектоники и геофизики им. Ю. А. Косыгина ДВО РАН, г. Хабаровск \\ E-mail: Taltykin@mail.ru
}

\begin{abstract}
Предложен новый механизм образования ильменитовой и магнетитовой серий гранитоидов в Сихотэ-Алиньском орогенном поясе. Существующие зоны распространения магматитов этих серий обусловлены региональным окислительно-восстановительным фоном, который существовал в период кристаллизации магм. В работе показана связь окислительно-восстановительного фона в литосфере региона с процессами субдукции в мел-палеогеновое время. Предложенный механизм образования ильменитовой и магнетитовой зон Сихотэ-Алиня объясняет также и различия окислительно-восстановительных условий при кристаллизации мезозойских магматитов в орогенах восточного и западного побережья Тихого океана.
\end{abstract}

Ключевые слова: магнетитовая серия, ильменитовая серия, граниты, слэб, окислительновосстановительные условия, Сихотэ-Алинь, Тихоокеанский пояс, редокс-фон.

DOI: $10.34078 / 1814-0998-2020-4-24-38$

\section{ВВЕДЕНИЕ}

Разделение гранитоидов на ильменитовую (восстановленную) и магнетитовую (окисленную) серии известно давно. Существует значительное количество современных исследований, посвященных степени окисленности континентальной и океанической литосферы, а также мантии (Wang et al., 2020; Li et al., 2020; Hong et al., 2020). При этом работ о механизмах возникновения региональных зон ильменитового магматизма в активных континентальных окраинах нет. Предполагается, что ильменитовые гранитоиды формируются в орогенных поясах в условиях сжатия. Это, в первую очередь, граниты типа S, реже I (Печерский, 1964; Ishihara,1977, 1998; Hart et al., 2004; Wendt et al., 2013). Считается, что они приобрели восстановленный состав за счет переработки углерода, содержащегося в осадках в виде захороненного органического вещества. Однако наши исследования, проведенные в Сихотэ-Алиньском орогенном поясе (САОП) на основе большого объема фактического материала, не подтверждают эти выводы. Во-первых, границы зон восстановленных магматитов в САОП секут гра2020

(C) Талтыкин Ю. В., Мишин Л. Ф., Коновалова Е. А., ницы аккреционных и осадочно-турбидитовых террейнов (Меркулова, Мишин, 2015; Мишин и др., 2019, 2020). Во-вторых, риолиты, андезиты и базальты Сихотэ-Алиня также делятся на две группы по окисленности железа, а для эффузивов влияние вмещающих пород не так велико (Мишин и др., 2003). Кроме того, существуют исследования, согласно которым для образования S-гранитов не требуется плавление осадочных толщ (Бахарев и др., 2005).

Региональные зоны ильменитовых и магнетитовых магматитов мезозойского возраста выявлены не только в САОП, но и пределах всего Тихоокеанского металлогенического кольца (Wendt et al., 2013). Причем на восточном обрамлении Тихоокеанского пояса преимущественно распространены магнетитовые зоны (рис. 1). Это противоречит как взглядам Д. М. Печерского, считающего, что в орогенных поясах должна быть ильменитовая серия, так и предположениям Ш. Ишихара о том, что в аккреционных комплекcax, богатых органикой, тоже должна быть ильменитовая серия. Таким образом, на данный момент нет приемлемого объяснения возникновению и существованию зон с ильменитовой и магнетитовой специализацией.

По мнению К. Сато, существование региональных зон свидетельствует об их генетической 


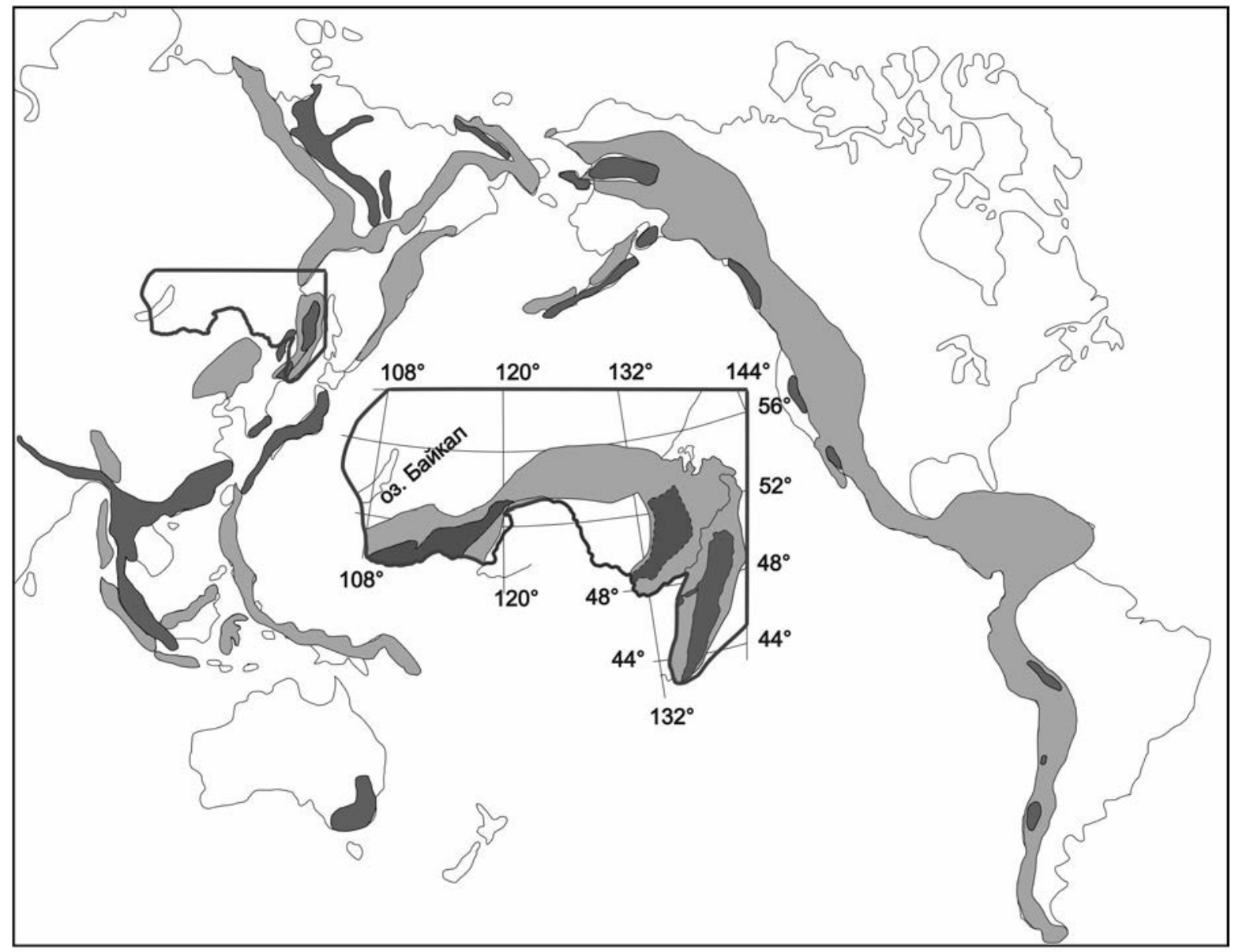

$\square 1 \square 2$

Puc. 1. Расположение зон ильменитовой (1) и магнетитовой (2) серий в Циркум-Пацифике по материалам (Ishihara, 1998; Wendt et al., 2013). На врезке дано распределение магнетитовых и ильменитовых зон МонголоОхотского и Сихотэ-Алиньского орогенных поясов (по материалам авторов)

Fig. 1. Location of ilmenite (1) and magnetite (2) series zones in Circum-Pacific (after Ishihara, 1998; Wendt et al., 2013). The inset shows the distribution of magnetite and ilmenite zones of the Mongol-Okhotsk and Sikhote-Alin orogenic belts (from the authors' data)

связи с региональными геодинамическими процессами (Sato, 2012). Целью настоящей работы и является выяснение механизма этой связи.

\section{1. РЕЗУЛЬТАТЫ ИССЛЕДОВАНИЙ, ПРОВЕДЕННЫХ В СИХОТЭ-АЛИНЬСКОМ ОРОГЕННОМ ПОЯСЕ}

1.1. Краткие теоретические предпосылки разделения магматитов на магнитные и немагнитные разности

Валентные формы элементов различно участвуют в геохимических процессах, в свою очередь валентное состояние поливалентных элементов определяется главным образом окислительными условиями среды магмообразования. Отсюда по соотношению валентных форм может быть решена обратная задача определения окислительных условий среды магмообразования.

Из всех поливалентных элементов наиболее доступным и практичным индикатором окисли- тельных условий и металлогенической специализации магматических пород выступает соотношение в породах и темноцветных минералах окисной и закисной валентных форм железа. С этим соотношением связан целый комплекс петрохимических, геохимических и петрофизических характеристик (см. таблицу), каждая из которых в отдельности и тем более в комплексе позволяет однозначно диагностировать магматические породы независимо от их возраста и формационно-петрографического состава на целые территории на определенные виды минерального сырья.

В условиях высокой фугитивности кислорода железо приобретает преимущественно трехвалентную форму. Трехвалентное железо имеет низкую растворимость в магматическом расплаве и уже на ранней стадии охлаждения и кристаллизации расплава связывается в магнетите. Из-за ранней кристаллизации магнетита остаточный расплав обедняется железом и кристаллизу- 
Таблица. Влияние окислительных условий на валентность железа в магматических породах, состав темноцветных минералов и металлогеническую специализацию пород

Table. Influence of oxidative conditions on the iron valence in igneous rocks, on the composition of darkcolored minerals, and on the metallogenic specialization of rocks

\begin{tabular}{|c|c|}
\hline $\begin{array}{l}\text { Окислительные условия } \\
\text { (магнетитовая серия) }\end{array}$ & $\begin{array}{c}\text { Восстановительные условия } \\
\text { (ильменитовая серия) }\end{array}$ \\
\hline $\mathrm{Fe}^{3+}$ & $\mathrm{Fe}^{2+}$ \\
\hline $\begin{array}{c}\text { Ранняя кристаллизация и высокое } \\
\text { содержание магнетита } \\
\mathrm{MS}>0.5 \cdot 10^{-3} \text { ед. СИ }\end{array}$ & $\begin{array}{c}\text { Ранняя кристаллизация темноцветных минералов, } \\
\text { следовые содержания магнетита и ильменита } \\
\text { (остаточная кристаллизация), } \\
\text { MS }<0.5 \cdot 10^{-3} \text { ед. СИ } \\
\end{array}$ \\
\hline $\begin{array}{c}\text { Низкая железистость темноцветных } \\
\text { минералов }\end{array}$ & Высокая железистость темноцветных минералов \\
\hline $\begin{array}{c}\text { Халькофильная рудная специализация } \\
\text { магматических пород }\end{array}$ & $\begin{array}{c}\text { Литофильная рудная специализация магматических } \\
\text { пород }\end{array}$ \\
\hline $\begin{array}{c}\text { Низко- и среднетемпературные } \\
\text { гидротермальные изменения (индикаторная } \\
\text { роль вторичных кварцитов) } \\
\end{array}$ & $\begin{array}{c}\text { Средне- и высокотемпературные гидротермальные } \\
\text { изменения }\end{array}$ \\
\hline $\begin{array}{c}\text { Месторождения Au-Ag эпитермальные, } \\
\text { Cu-Мо порфировые }\end{array}$ & Месторождения Sn, W \\
\hline
\end{tabular}

ющиеся вслед за магнетитом темноцветные минералы (биотит, роговая обманка, пироксены и оливин) вследствие дефицита остаточного железа отличаются пониженной железистостью. Это еще один дополнительный признак для диагностики пород магнетитовой серии. Преимущественно магнетитовый состав акцессорного рудного минерала и его высокие содержания создают повышенную магнитную восприимчивость (MS) пород, позволяющую с помощью каппаметра непосредственно в поле картировать зоны окислительно-восстановительной обстановки формирования магматитов. Это особенно актуально в тех случаях, когда граница зон пересекает однородные в возрастном и петрографическом отношении изолированные тела магматических пород.

В восстановительных условиях железо находится преимущественно в подвижной двухвалентной форме. В этом случае оно в основном концентрируется в темноцветных минералах и лишь его избыток связывается в ильмените и магнетите, и, как правило, в виде единичных зерен. Именно такой процесс обусловливает низкую, часто почти нулевую магнитную восприимчивость магматических пород ильменитовой серии. Наряду с железом и другие поливалентные элементы ( $\mathrm{Sn}, \mathrm{Cu}, \mathrm{Eu}$ и др.) могут выступать в качестве индикаторов окислительно-восстановительных условий кристаллизации магматических пород.

Магнитная восприимчивость образца показывает отношение намагниченности единицы объема породы к величине напряженности магнитного поля Земли. По этому параметру все магматиты можно отнести к магнитным (магнетитовая серия - MC) или немагнитным (ильменитовая серия - ИС). Названия серий являются несколько условными, поскольку в образцах магнетитового ряда содержится всего до 1-2\% минерала магнетита, а в ильменитовых породах до 0.1-0.2\% ильменита (Печерский, 1964; Ishihara, 1977), но в то же время общепринятыми до сих пор. Важным моментом является также ситуация с оловом. Именно восстановленный флюид способен переносить значительные объемы $\mathrm{Sn}^{2+}$ (Борисов и др., 1991; Linnen et al., 1995), а вот месторождения образуются при фракционной кристаллизации на заключительной стадии, когда олово концентрируется в остаточном растворе.

\section{2. Методика работ и выделение магнети-} товых и ильменитовых серий

В течение многих лет авторы проводили исследования магматитов Сихотэ-Алиньского орогенного пояса. Только за последние годы выполнено около 500 точек наблюдений с отбором образцов и измерениями их MS. Также измерялась магнитная восприимчивость в обнажениях и по профилям вдоль выходов магматитов. По комплексу материалов, включающих различные петрофизические и геохимические анализы образцов, была построена схема распространения магматитов ильменитовой и магнетитовой серий (рис. 2) (Мишин и др., 2020). В ней же приведены таблицы с результатами анализов. Настоящая работа является завершающим этапом этих исследований.

При выделении зон использовались следующие данные:

магнитная восприимчивость как образцов, так и измеренная в обнажениях, включая заме- 


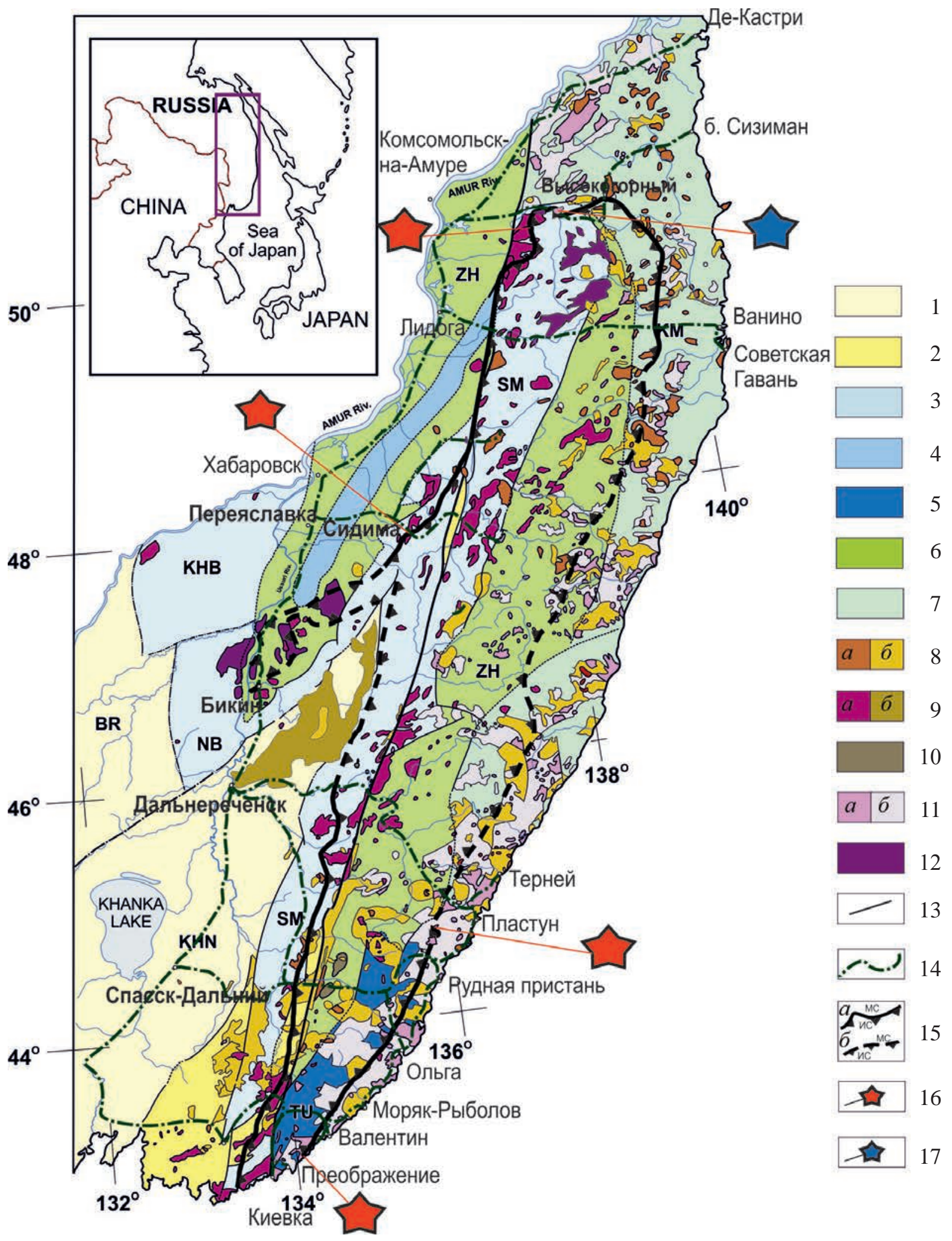

Puс. 2. Геологическая карта Сихотэ-Алиня по (Grebennikov et al., 2016) с добавлениями авторов: 1 - раннепалеозойские континентальные блоки: BR - Буреинский, KHN - Ханкайский; 2 - палеозойские окраинноконтинентальные террейны, надвинутые на юрские аккреционные призмы; 3 - террейны юрской аккреционной призмы, содержащие фрагменты палеозойских офиолитов, кремнистых сланцев и известняков и триасовых кремнистых сланцев: SM - Самаркинский, NB - Наданьхада-Бикинский, КНВ - Хабаровский; 4 - террейн раннемеловой аккреционной призмы, содержащий фрагменты юрских базальтов, кремнистых сланцев и пород раннемеловой островной дуги; 5 - террейн раннемеловой (неоком) аккреционной призмы, содержащий фрагменты девонско-триасовых известняков, базальтов и позднепалеозойских и триасово-юрских кремнистых сланцев и аргиллитов: TU - Таухинский; 6 - террейн раннемелового турбидитового бассейна: ZН - Журавлевско- 
Амурский; 7 - раннемеловая островная дуга: КМ - Кемская; 8 - палеогеновые гранитоиды $(a)$ и вулканические породы (б); 9 - поздний альб - раннесеноманские гранитоиды (a) и вулканические породы (б); 10 - позднеальбские габбро-монцограниты и сиениты; 11 - позднемеловые гранитоиды (a) и вулканические породы (б); 12 - готерив-аптские гранитоиды; 13 - Центральный Сихотэ-Алиньский разлом; 14 - линии опробования магматических пород; 15 - граница распространения пород магнетитовой (МС) и ильменитовой (ИС) серий, выделенная авторами по комплексу признаков $(a)$ и по соотношению $\mathrm{Fe}_{2} \mathrm{O}_{3} /\left(\mathrm{Fe}_{2} \mathrm{O}_{3}+\mathrm{FeO}\right)(б) ; 16,17$ - интрузивы, на которых задокументирована зона перехода от ильменитовой серии к магнетитовой; 17 - Аксакинский массив

Fig. 2. Geological map of the Sikhote-Alin according to (after Grebennikov et al., 2016 complemented by the authors). 1 - Early Paleozoic continental blocks: BR - Bureya, KHN - Khanka; 2 - Paleozoic marginal-continental terranes, upthrusted on the Jurassic accretionary prisms; 3 - terranes of the Jurassic accretionary prism containing fragments of Paleozoic ophiolites, silicious schists and limestones and Triassic silicious chists: SM - Samarka, NB - Nadankhada-Bikin, KHB - Khabarovsky; 4 - terrane of the Middle Cretaceous accretionary prism containing fragments of Jurassic basalts, silicious schists, and rocks of the Early Cretaceous island arc; 5 - terrane of the Early Cretaceous (Neocomian) accretionary prism, with fragments of Devonian-Triassic limestones, basalts and Late Paleozoic and Triassic-Jurassic silicious schists and argillites: TU - Taukha; 6 - terrane of the Early Cretaceous turbidite basin: ZH Zhuravlyovka-Amur; 7 - Early Cretaceous island arc: KM - Kema; 8 - Paleogene granitiods (a) and volcanic rocks (б); 9 - Late Albian - Early Cenomanian granitoids $(a)$ and volcanic rocks (б); 10 - Late Albian gabbro-monzogranites and syenites; 11 - Late Cretaceous granitoids (a) and volcanic rocks (б); 12 - Hauterivian - Aptian granitoids; 13 - Central Sikhote-Alin Fault; 14 - magmatic rock sampling profiles; 15 - boundary between the magnetite rock series (MS) and ilmenite (IS) rock series, distinguished by the authors beset of indications (a) and by the $\mathrm{Fe}_{2} \mathrm{O}_{3} /\left(\mathrm{Fe}_{2} \mathrm{O}_{3}+\mathrm{FeO}\right)$ ratio (б); 16, 17 - intrusive massifs, where the zone oftransition from the ilmenite to the magnetite rock series is documented; 17 - Aksakinsky massif

ры вдоль профилей с шагом 2-10 м. При $\mathbf{M S}<$ $0.5 \cdot 10^{-3}$ ед. СИ для интрузивов и $\mathbf{M S}<3 \cdot 10^{-3}$ ед. СИ для эффузивов зона считается ильменитовой. В дальнейшем данные по MS сопоставлялись с картами аномального магнитного поля;

коэффициенты окисленности образцов, рассчитанные по соотношению $\mathrm{K}=\mathrm{Fe}_{2} \mathrm{O}_{3} /\left(\mathrm{Fe}_{2} \mathrm{O}_{3}+\right.$ $\mathrm{FeO})$. При $\mathrm{K}<0.3$ - зона ильменитовая;

железистость темноцветных минералов, состав рудного минерала (магнетит-ильменит), вес магнитной фракции;

спектр редкоземельных элементов (РЗЭ) проб, европиевый минимум (Eu) свидетельствует об ильменитовых магматитах (Мишин, 2010);

наличие месторождений или рудопроявлений олова (или $\mathrm{Sn}-\mathrm{W})$, связанных с интрузивами. Олово является практически 100\%-ным критерием ильменитовой серии.

Все перечисленные элементы позволяют достаточно четко разделять ИС и МС.

Опыт китайских геологов по измерению фугитивности кислорода цериевыми оксибарометрами, в первую очередь на юго-востоке Китая, дает более детальную градацию степени окисленности гранитоидов, но это не несет принципиально другой информации (Guo et al., 2018). Oт MS через коэффициент окисленности можно перейти к фугитивности кислорода.

В пределах Сихотэ-Алиня ильменитовая зона магматитов (см. рис. 2) обладает рядом особенностей. Это:

протяженность вдоль побережья около 1 тыс. км при ширине 150-250 км;

возраст магматитов от готерива до палеоцена; широкий петрологический спектр интрузивов от S- и I- до А-типов и эффузивов от риолитов до базальтов. При этом породы одного и того же возраста и состава могут быть и в МС, и в ИС.

Схожие характеристики наблюдаются и в аналогичных зонах остальных регионов ЦиркумПацифики.

Все вышесказанное привело нас к выводу, что окислительно-восстановительные условия (редокс-условия) кристаллизации не связаны ни с петрологическим составом пород, ни с их возрастом, а являются фоном, на котором происходит процесс кристаллизации. Только этим можно объяснить как длительное существование протяженных региональных зон с различными окислительно-восстановительными условиями, так и наличие на границах этих зон массивов, через которые проходит линия раздела магнетит ильменит (рис. 3). Достаточно сложно объяснить это явление раздельным подъемом окисленной и восстановленной магм в зону кристаллизации. В настоящее время на Сихотэ-Алине авторами выделено несколько таких массивов (по ним готовится отдельная статья).

Согласно ряду исследований (Кадик, Луканин, 1986; Кадик, 2003; Летников, 2006), известно, что существует дегазация Земли, при этом флюидный поток из мантии, как правило, является восстановленным (водородные соединения). В конкретном месте конвергентных окраин редокс-фон складывается из мантийного (нижнемантийного) восстановленного потока флюидов и регионального потока, связанного с погружающимся слэбом. В настоящей работе мы рассматриваем только редокс-фон регионального уровня, возникший при взаимном влиянии океанических и континентальных плит как определяющих факторов в мезозойской истории САОП 


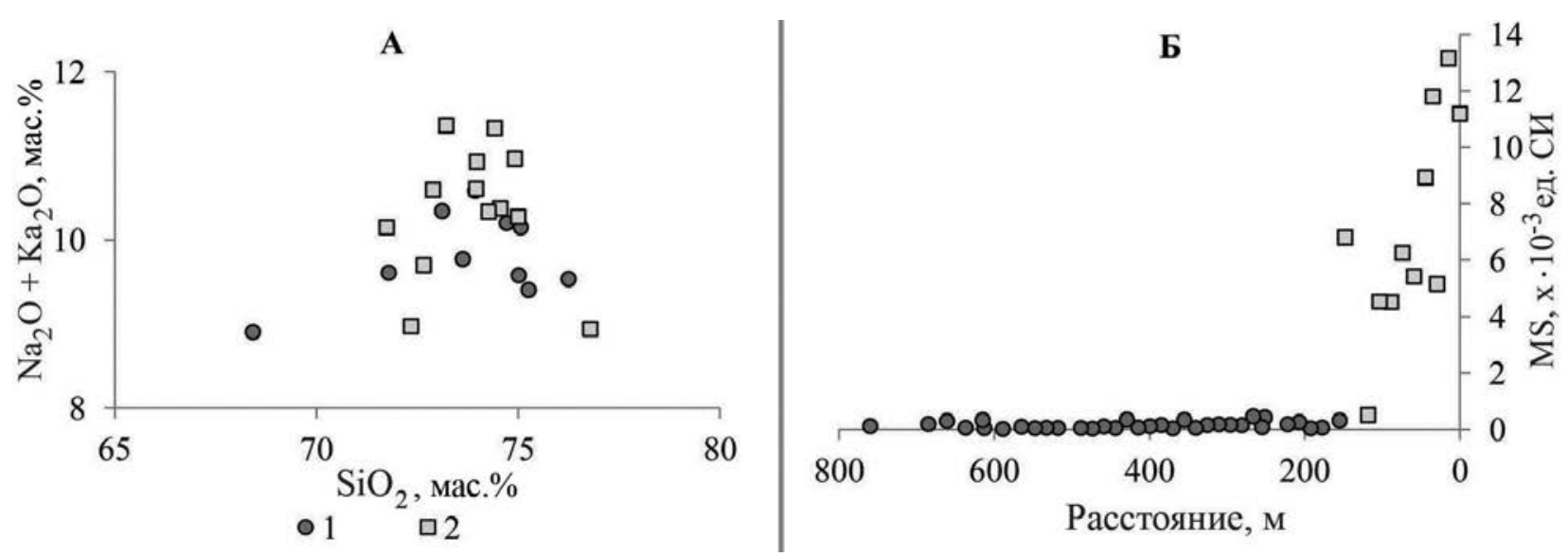

Puc. 3. Химический состав пород Аксакинского массива (А): 1 - ильменитовая серия, 2 - магнетитовая серия и профиль измерений магнитной восприимчивости от Аксакинского перевала до западного контакта Аксакинского массива с вмещающими породами (Б)

Fig. 3. Chemical composition of the Aksakinsky massif rocks (A): 1 - ilmenite series, 2 - magnetite series and the profile of magnetic susceptibility measurements from the Aksakinsky pass to the Aksakinsky massif western contact with the host rocks $(\mathbf{C})$

и Тихоокеанского обрамления в целом. Надо отметить, что геологическая деятельность других факторов, таких как плюмы, мантийные течения, тектонические напряжения от удаленных блоков земной коры и т. п., также может оказывать воздействие на окислительно-восстановительные условия кристаллизации магматитов. СихотэАлинь является достаточно удобным объектом Циркум-Пацифики в силу как своей изученности дальневосточными геологами и геофизиками, так и «относительно простого» геодинамического режима мезозойской активизации. В частности, САОП возник на океанической коре, и оловоносность ильменитовой зоны можно считать «первичной», а не связанной с предыдущими породами-протолитами (Romer, Kroner, 2016; Мишин и др., 2020).

\section{2. СОВРЕМЕННОЕ СОСТОЯНИЕ ПРОБЛЕМЫ СУЩЕСТВОВАНИЯ РЕДОКС-ФОНА}

\section{1. Редокс-состояние глубинных флюидов}

Выяснению окислительно-восстановительного потенциала флюидов земной коры и мантии посвящено немало публикаций. По материалам ряда исследователей редокс-фон основной части мантии восстановленный и характеризуется фугитивностью кислорода $\mathrm{fO}_{2}$ на несколько логарифмических единиц ниже буфера фаялиткварц-магнетит (FQM) (Wang et al., 2020; Li et al., 2020; Hong et al., 2020). Это подтверждает ранее сделанные выводы (Кадик, Луканин, 1986; Кадик, 2003; Летников, 2006). В зонах субдукции действуют разнонаправленные окислительновосстановительные процессы. С одной стороны, это окисление за счет дегидратации слэба, с другой - погружение углерода с карбонатными породами и обогащенными органикой осадками приводит к возникновению восстановительного потенциала при формировании магматических пород (Добрецов и др., 2015; Соболев и др., 2015). Таким образом, в зонах субдукции до глубин 200 км возможно существование участков как с окислительными, так и с восстановительными свойствами глубинного флюида, при этом основным фоном является все-таки окисленный.

В заключение отметим, что на данный момент нет общепризнанной концепции редокс-условий в литосфере и мантии Земли, особенно с развитием представлений о плюмах, конвекции, апвеллинге, мантийном клине и т. п.

\section{2. Редокс-состояние литосферы в зонах} субдукции и коллизии

Основным источником воды в надсубдукционной литосфере предполагается процесс дегидратации слэба (рис. 4) (Добрецов и др., 2017; Evans et al., 2017; Malaspina et al., 2017). Так, по мнению (Deschamps et al., 2013; Merkulova et al., 2017), большая часть воды теряется океанической плитой на глубине до 120-170 км за счет преобразования серпентинитов, Н. Л. Добрецов (Добрецов и др., 2015) допускает образование силикатного надкритического флюид-расплава на глубине до 150-200 км.

Кроме того, есть вероятность появления до $1-2 \%$ воды в застойной зоне слэба (мантийная транзитная зона «МТ3» 410-660 км) в результате различных реакций дегидратации. На возможность этого процесса указывает ряд авторов (Lei et al., 2013; Wang et al., 2018; Kaminsky, 2018; Kuritani et al., 2019) (рис. 4). Таким образом, области верхней мантии и литосферы над слэбом до глубины погружения плиты 150-200 км и ниже 400- 


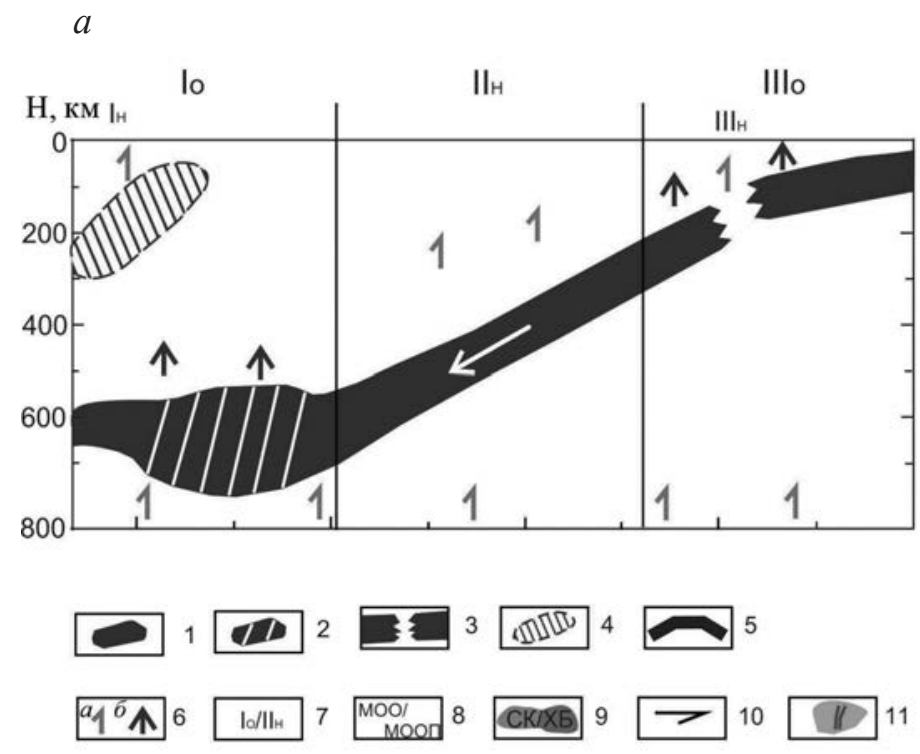

6

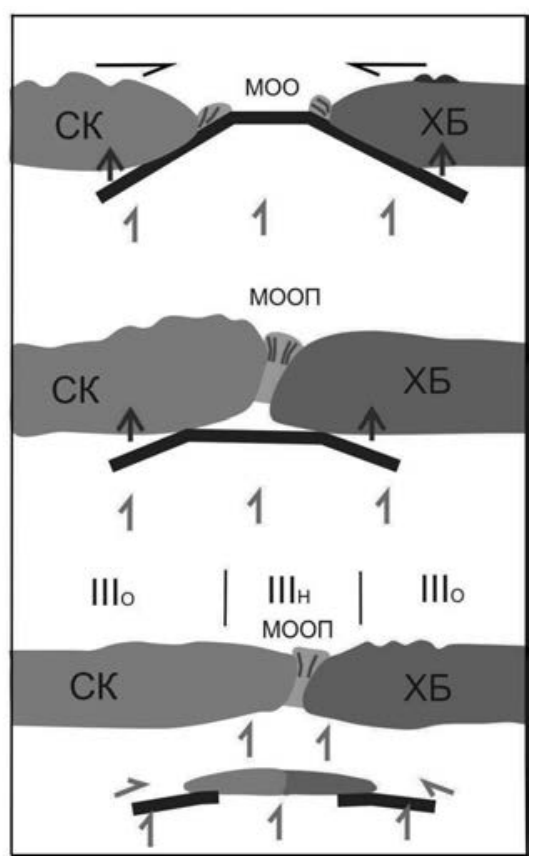

Puc. 4. Схема возможного возникновения зон окисленного (о) и восстановленного (н) флюидных потоков: $a$ - при погружении субдуцирующей плиты, $\sigma$ - при столкновении двух континентальных блоков. За основу взяты рисунки из работ: $a$ - Lei et al., 2013; Kuritani et al., 2019; $\sigma$ - Tang et al., 2018. 1 - погружающийся слэб; 2 - застойный слэб; 3 - зона разрыва слэба; 4 - остаток дегидратированного слэба или кратонной литосферы; 5 - океаническая плита; 6 - поток флюидов: $a$ - восстановленных, 6 - окисленных; 7 - зоны подъема окисленного (о) или восстановленного (н) флюида; 8 - МОО - Монголо-Охотский океан, МООП - Монголо-Охотский орогенный пояс; 9 - СК - Сибирский кратон, ХБ - Хинганский блок; 10 - направление движения блоков; 11 аккреционный комплекс

Fig. 4. Diagram showing a possible occurrence of zones of oxidized (о) and reduced (н) fluid flows: $a$ - at subsidence of the subducting plate; $\sigma$ - at collision of two continental blocks. The diagram is based on the figures from: $a$-Lei et al., 2013; Kuritani et al., 2019; 6 -Tang et al., 2018. 1 -subsiding slab; 2 -stagnant slab; 3 -zone of slab fracture; 4 - remnant of dehydrated slab or craton lithosphere; 5 - oceanic plate; 6 - fluid flow: $a$-reduced, $\sigma$-oxidized; 7 - zones of oxidized (o) or reduced ( $\mathrm{H}$ ) fluid rising; 8 - MOO - Mongol-Okhotsk ocean, MOOП - Mongol-Okhotsk suture belt; 9 - CК - Siberian craton, ХБ - Khingan block; 10 - block movement direction; 11 - accretionary complex

500 км (рис. 4, $a$, зона Іо и IIIо) являются потенциально окисленными.

Ситуация с зонами восстановленного флюида несколько сложней. Появление их в зонах субдукции может происходить по разным сценариям:

флюиды в литосфере и верхней мантии над центральной обезвоженной частью слэба (200 400-500 км) будут обладать восстановительными свойствами (рис. 4, $a$, зона ІІн). Этот интервал, на наш взгляд, является основным при формировании региональных зон магматитов ильменитовой серии;

окисленный флюидный поток, идущий из зоны застойной плиты (или участка захоронения нескольких слэбов (Wang et al., 2018), при столкновении с обезвоженными остатками предыдущего слэба или блоками низов кратонной литосферы может восстанавливаться. Подобный механизм рассмотрен в работах (Lei, 2012; Lei et al.,
2013), где предполагается экранирующее влияние остаточной литосферы в юго-восточном Китае (рис. 4, $a$, зона Ін);

при разрыве слэба в процессе смены геодинамической обстановки (образование «слэбокон») образуются граниты А-типа (Khanchuk et al., 2016; Grebennikov et al., 2016) и восстановленный флюидный поток может подниматься из подлитосферной мантии (рис. 4, $a$, зона ІІІн). В этих случаях возможно возникновение протяженных зон ильменитовых магматитов, однако над погруженной частью слэба останется магнетитовая зона;

при коллизии двух континентальных плит и разрушении океанической литосферы также может возникнуть восстановленный поток из мантии в зоне декомпрессии (рис. 4, б, зона ІІІн). Такие зоны столкновения жестких блоков будут проявляться поясами гранитоидов ильменитовой серии. Подобную картину мы, возмож- 
но, видим в западной части Монголо-Охотского орогенного пояса (Мишин и др., 2019): ильменитовая серия расположена в районе схождения континентальных плит, а магнетитовая ее обрамляет. Однако океаническая плита не всегда разрушается, и тогда вся зона орогенеза остается магнетитовой.

\section{3. ОБСУЖДЕНИЕ}

\section{1. Магнетит-ильменитовые зоны Сихотэ- Алиньского орогенного пояса, связь с геоди- намикой}

На континентальных окраинах Тихого океана участки распространения пород магнетитовой и ильменитовой серий выделяются в виде протяженных зон. При этом магнетитовая серия от океана в глубь материка сменяется ильменитовой (за исключением Западно-Американского побережья), что предполагает некоторые общие закономерности их возникновения.

Согласно схеме тектонической реконструкции (Khanchuk et al., 2016), большинство раннемеловых магматических пород в САОП сформировалось в эпоху возникновения «слэб-окон» из астеносферных инъекций. Значительную роль в образовании магматитов альб-сеноманского возраста сыграли трансформные обстановки вдоль востока Евразии (Grebennikov et al., 2016; Kemkin et al., 2016; Ханчук и др., 2019; Диденко, Ханчук, 2019).

Несколько иной взгляд на юрско-меловую историю региона у Л. Дмитриенко (Dmitrienko et al., 2018) и М. Сана (Sun et al., 2018). После 150 млн (до 80 млн) лет шла субдукция палеоТихоокеанской плиты (Sun et al., 2018). Co 120 млн лет из-за появления в зоне МТ3 «застойного» участка слэба начинается откат плиты (roll-back) и образование вулканической дуги и задугового бассейна. Сихотэ-Алинь при этом находится, в основном, над зоной обезвоженной части слэба.

Несмотря на различия в тектонических построениях, можно предположить, что основное время орогенеза и связанного с ним синорогенного магматизма в Сихотэ-Алине - это готерив сеноман, при этом пик приходится на альб - сеноман (Ханчук и др., 2019). Завершение орогенеза происходит в позднем мелу - палеоцене. Таким образом, флюидный поток уже с готерива на территории значительной части орогена был восстановленный. В то же время вдоль побережья образовывались магматиты магнетитовой серии под воздействием окисленного флюида погружающейся части слэба. В это время плиту Изанаги сменяла Тихоокеанская плита.

Для Сихотэ-Алиня можно сделать вывод, что изменение тектонической обстановки субдукции на скольжение и обратно (Диденко, Ханчук, 2019), откат плиты (Sun et al., 2018) и т. п. в те- чение мела - палеогена не повлияли непосредственно на существование потока восстановленных флюидов в центральной полосе орогенной зоны, хотя пограничные участки могли претерпевать изменения. Субдукционные процессы, включая трансформные обстановки, играют определенную роль в формировании самой орогенной зоны, которая на длительный срок становится участком разуплотнения и повышенной проницаемости для мантийных растворов, имеющих восстановительный характер. Субдукция также способствовала возникновению пород магнетитовой серии в надсубдукционной зоне, обогащенной водным флюидом дегидратирующего слэба.

Подобная модель субдукции предполагает внешнюю (к океану) зону распространения магматических пород ильменитовой серии (за счет аккреции и последующего орогенеза, возникновения «слэб-окон», астеносферных инъекций и потока мантийных восстановленных флюидов) и внутреннюю - магнетитовую, состоящую из окисленных надсубдукционных вулканоплутонических пород островной дуги. При этом редокс-условия являются лишь фоном, на котором происходят процессы магматизма. Стоит отметить тот факт, что в региональных зонах восстановленного флюида могут существовать локальные участки окисленных магматитов.

Предложенный механизм можно проиллюстрировать с помощью схематического разреза (рис. 5). Мы попытались оценить мощность аккреционной призмы на начало готерива (считая плиту плоской, что не всегда соответствует действительности). За 50 млн лет движения со средней скоростью 8 см/год (80 км/млн лет) плита Изанаги должна пройти около 4000 км (Seton et al., 2012), что не противоречит материалам современной сейсмотомографии (Meer et al., 2018). При средней мощности осадков до 2 км аккреционный блок составит 8000 км² (в двухмерной модели) или примерно $13 \cdot 600$ км; сюда войдут как аккреционные отложения юры и раннего мела, так и образования Журавлевского турбидитового бассейна. К этому времени в литосфере региона будут сформированы зоны с восстановленным и окисленным фоном. В процессе орогенеза при сжатии (как с запада, так и с востока) в 2 раза возникнет земная кора мощностью более 20 км (согласно мощности осадочно-вулканогенного и гранитно-метаморфического слоев на разрезе ГСЗ вдоль профиля Бикин - В. Кема (Аргентов и др., 1976). Изменение направления движения плиты Изанаги приведет, на наш взгляд, сначала к обрыву слэба, потом к сжатию аккреционного комплекса и лишь потом к скольжению вдоль Евро-Азиатского материка. При этом не исключено, что в альб-сеноманское время магматический пояс (Ханчук и др., 2019) будет трассиро- 

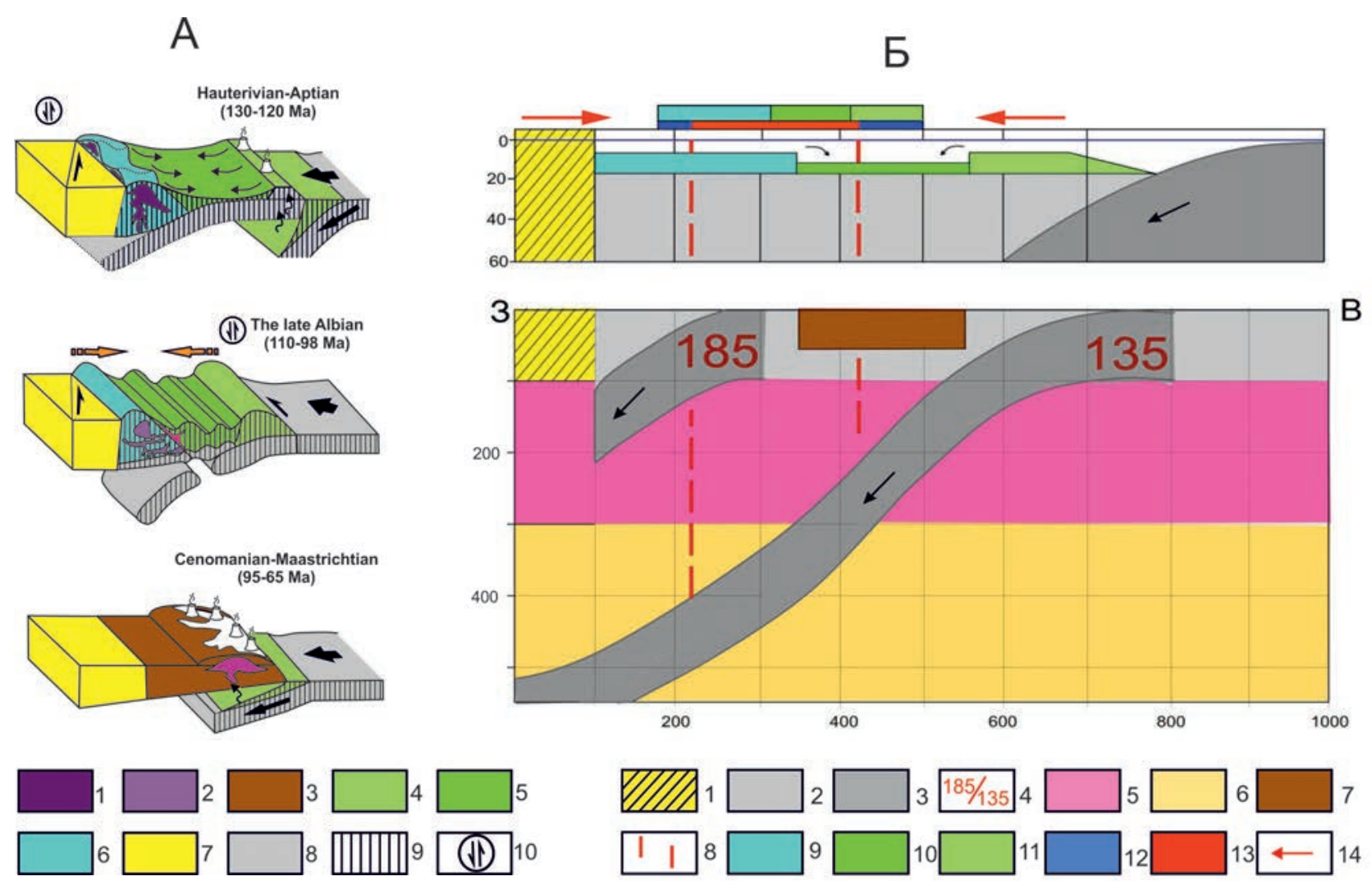

Puc. 5. Модель субдукции-аккреции на начало готерива по материалам (Seton et al., 2012) (Б) на основе (Grebennikov et al., 2016) (A). A: 1 - готерив-аптские гранитоиды; 2 - позднеальбские - раннесеноманские гранитоиды; 3 - раннемеловая континентальная литосфера; 4 - раннемеловая островодужная система; 5 - раннемеловой турбидитовый бассейн; 6 - юрская аккреционная призма; 7 - раннепалеозойская континентальная литосфера; 8 - палео-Тихоокеанская плита; 9 - океаническая литосфера; 10 - трансформная граница плит. Б: 1 - континентальная литосфера; 2 - океаническая литосфера; 3 - погружающийся слэб (плита Изанаги); 4 - 185/135 - возможное место нахождения плиты Изанаги в начале субдукции (185 млн лет назад) и к началу готерива (135 млн лет); 5 - астеносфера; 6 - верхняя мантия; 7 - возможный размер аккреционного комплекса к 135 млн лет; 8 - граница между окисленным и восстановленным флюидом; 9 - юрский аккреционный комплекс; 10 - турбидитовый раннемеловой бассейн; 11 - раннемеловой аккреционно-вулканогенный комплекс; 12 - зона окисленного флюида (магнетитовая серия); 13 - зона востановленного флюида (ильменитовая серия); 14 - направление сжатия

Fig. 5. Model of subduction/accretion by the beginning of Hauterivian after Seton et al., 2012 (Б) based on Grebennikov et al., 2016 (A). A: 1 - Hauterivian-Aptian granitoids; 2 - late Albian-Early Cenomanian granitoids; 3 - Early Cretaceous continental lithosphere; 4 - Early Cretaceous island arc system; 5 - Early Cretaceous turbidite basisn; 6 - Jurassic accretionary prism; 7 - Early Paleozoic continental lithosphere; 8 - Paleo-Pacific plate; 9 - oceanic lithosphere; 10 - transform plate boundary. Б: 1 - continental lithosphere; 2 - oceanic lithosphere; 3 - subsiding slab (Izanagi Plate); 4 - 185/135 mln years ago - probable location of the Izanagi plate at the beginning of subduction (185 mln years ago) and by the early Hauterivian (135 mln years ago); 5 - astenosphere; 6 - upper mantle; 7 - feasible size of an accretionary complex by $135 \mathrm{mln}$ years ago; 8 - boundary between the oxidized and reduced fluid; 9 - Jurassic accretionary complex; 10 - Early Cretaceous turbidite basin; 11 - Early Cretaceous accretionary volcanogenic complex; 12 - zone of an oxidized fluid (magnetite series); 13 - zone of a reduced fluid (ilmenite series); 14 - direction of compression

вать на поверхности зону трения плит, в которой выделяется огромная сейсмическая и тепловая энергия. Дальнейшее возобновление субдукции приведет к образованию нового слэба, предыдущий будет погружаться и растворяться в мантии. Такой цикл может повторяться.

Как видно из рис. 5, зона восстановленного флюида на поверхности останется надолго. При следующей субдукции она вряд ли сильно изменится.

\section{2. Магнетит-ильменитовые зоны Тихо- океанского пояса}

Всем орогенным поясам Сихотэ-Алиня, Японии, Восточного Китая, Калифорнии ит. п. обычно соответствуют хорошо выраженные региональные минимумы силы тяжести. Их интерпретация приводит ряд авторов к предположению о наличии разуплотнения в этих зонах до глубин в десятки и даже первые сотни километров. Также здесь увеличена мощность земной коры, 
наблюдаются участки пониженных скоростей по данным сейсмических зондирований и высокопроводящие области в литосфере. Стоит отметить, что все приведенные геофизические материалы относятся именно к орогенам, а не к ильменитовым или магнетитовым зонам. Они отражают, в первую очередь, процессы изостазии, тем более что ильменитовые гранитоиды имеют несколько большую плотность, чем магнетитовые (Романовский,1987). Также исследователи приходят к выводу о схожести глубинного строения Кордильер и Сихотэ-Алиня по комплексу геофизических измерений и геологических признаков и считают, что американская ветвь притихоокеанских орогенных сооружений так же, как и азиатская, обязана своим происхождением единым по генетической сути глубинным процессам позднефанерозойской тектономагматической активизации (Романовский,1987). При этом нет принципиальных различий в строении Тихоокеанских орогенных поясов близкого возраста, включающих в себя аккреционные комплексы океанических плит. В то же время выявлено (Ishihara, 1998), что магнетитовые и ильменитовые гранитоиды неоднородно распределены по обе стороны Тихого океана (см. рис. 1). Гранитоиды ИС доминируют в западной части Тихого океана, в то время как гранитоиды МС преобладают в Восточно-Тихоокеанском орогенном поясе, т. е. различие состоит в редокс-условиях кристаллизации магматитов.

Рассматривая вопрос об окислительно-восстановительных условиях кристаллизации магматитов в орогенах запада Северо-Американского континента, отметим следующее. Согласно P. G. DeCelles (2004), Кордильерский орогенный пояс был тектонически консолидирован в течение позднего юрского времени и состоял в основном из осадочных и метаосадочных пород, накопившихся ранее вдоль западной окраины Лаврентии. Начиная с раннего мела происходит постепенное увеличение взаимной скорости плиты Фараллон и Северо-Американского континента. К концу мела - эоцену она увеличивается в 7-10 раз, достигая 10-15 см/год. При этом континент «наезжал» на океаническую плиту (Seton et al., 2012), в результате чего возникла плоская субдукция. Основная часть орогенного пояса при этом попадала в зону дегидратации слэба, и магматиты формировались на фоне окисленного флюидного потока. Материк сдирал «бульдозером» осадки с океанической плиты и наползал на неe (Monger, Gibson, 2019). С другой стороны, во время плоской субдукции материал соскребался с основания литосферы континентальной мантии (Gutscher, 2018), т. е. глубина погружения океанической плиты под континентом не превышала 200 км. Поэтому в процессе возникновения орогенов Кордильер и Анд получался окисленный флюидный поток от дегидратирующего слэба. На наш взгляд, это более приемлемое объяснение, чем истощение осадочного углерода в аккреционных комплексах Америки (Sato, 2012).

\section{ЗАКЛЮЧЕНИЕ}

Распределение ильменитовых и магнетитовых зон в САОП и в целом в ЦиркумПацифике связано, на наш взгляд, с изменением окислительно-восстановительных свойств мантийного флюида при переходе от образований островных дуг, находившихся в зоне дегидратации слэба, к орогенным комплексам, обладавшим повышенной проницаемостью литосферы для восстановленных мантийных растворов. Это относится к северной, западной и юго-западной частям Тихоокеанского кольца. Субдукция, в данном случае, является механизмом образования орогенов и вулканических дуг в мезозой - раннекайнозойское время. Это привело к формированию вытянутых вдоль береговой линии орогенных зон (содержащих ильменитовую серию) и придвинутых к ним со стороны океана поясов островных дуг (магнетитовая серия). На Восточно-Тихоокеанском побережье континентальные блоки Америки надвигались на субдуцирующие океанические плиты. Поэтому при возникновении орогенов Кордильер и Анд восходящий флюидный поток оказался в основном окисленным. Даже, несмотря на наличие большого количества аккреционных осадочных отложений, практически не возникло восстановленного магматизма, аналогичного ильменитовой зоне в СихотэАлине. Ряд ильменитовых батолитов Америки (обычно I-типа) имеет ограниченное распространение и, возможно, связан с зонами разломов плит или с обычной (а не плоской) субдукцией.

Таким образом, изучение редокс-условий кристаллизации магматитов мезозойского времени может давать дополнительные сведения как о металлогении регионов, так и (наряду с другими материалами) о тектонических процессах в зонах активных континентальных окраин.

\section{БЛАГОДАРНОСТИ}

Коллектив авторов благодарит рецензента за ценные советы и замечания, позволившие значительно улучшить качество представленного материала. Мы также благодарны сотрудникам лаборатории тектоники осадочных бассейнов ИТиГ ДВО РАН д. г.-м. н. Галине Леонтьевне Кирилловой и к. г.-М. н. Елене Петровне Развозжаевой за неоценимую помощь в проведении исследований и подготовке статьи. 


\section{ЛИТЕРАТУРА}

Аргентов В. В., Гнибиденко Г. С., Попов А. А., Потапьев $C$. В. Глубинное строение Приморья (по данным ГСЗ). Москва : Наука, 1976. 90 с.

Бахарев А. Г., Шкодзинский В. С., Жданов Ю. Я. Графитсодержащие кислые магматические породы Тас-Кыстабытского магматического пояса ВерхояноКолымской складчатой области // Отечественная геология. 2005. № 5. С. 54-57.

Борисов А. А., Жаркова Е. В., Кадик А. А., Кравчук И. Ф., Луканин О. А., Малинин С. Д., Шилобреева C. H. Флюиды и окислительно-восстановительные равновесия в магматических системах. Москва : Наука, 1991. 256 с.

Диденко А. Н., Ханчук А. И. Смена геодинамических обстановок в зоне перехода Тихий океан - Евразия в конце раннего мела // ДАН РФ. 2019. Т. 487, № 4. C. 186-191. DOI: https://doi.org/10.31857/S086956524874405-408

Добрецов Н. Л., Кулаков И. Ю., Литасов К. Д., Кукарина E. В. Значение геологии, экспериментальной петрологии и сейсмотомографии для комплексной оценки субдукционных процессов // Геология и геофизика. 2015. Т. 56, № 1-2. C. 21-55. DOI: 10.15372/ GiG20150102

Добрецов Н. Л., Симонов В. А., Кулаков И. Ю., Котляров А. В. Проблемы фильтрации флюидов и расплавов в зонах субдукции и общие вопросы теплофизического моделирования в геологии // Там же. 2017. Т. 58, № 5. C. 701-722. DOI: 10.15372/GiG20170503

Кадик A. A. Восстановленные флюиды мантии: связь с химической дифференциацией планетарного вещества // Геохимия. 2003. № 9. С. 928-940.

Кадик А. А., Луканин О. А. Дегазация верхней мантии при плавлении. Москва : Наука, 1986. 95 с.

Летников $\Phi$. А. Сверхглубинные флюидные системы Земли. 2006. http://csr.spbu.ru/pub/RFBR publications/articles/geosciences/2006/sverhglubinnie _ flyuidnie_sistemi_Zemli_06_geo.pdf

Меркулова Т. В., Мишин Л. Ф. Окислительно-восстановительные процессы в мезозойско-кайнозойских вулканоплутонических системах и их роль в формировании региональных гравитационных и магнитных аномалий Дальнего Востока // Тихоокеанская геология. 2015. Т. 34, № 6. С. 112-124.

Мишин Л. Ф. Геохимия европия в магматических породах окраинно-континентальных вулканогенных поясов // Геохимия. 2010. № 6. С. 618-631.

Мишин Л. Ф., Кириллова Г. Л., Меркулова Т. В., Коновалова $E$. А. Окислительные условия формирования постколлизионного магматизма и металлогении западного сектора Монголо-Охотского орогенного пояса // Тихоокеанская геология. 2019. T. 38, № 4. C. 3-12. DOI: 10.30911/0207-4028-2019-38-4-3-12

Мишин Л. Ф., Коновалова Е. А., Талтыкин Ю. В., Крутикова В. О., Добкин С. Н., Юрченко Ю. Ю., Штарева А. В. Окислительные условия и связанные с ними геохимическая и металлогеническая зональности магматических образований Сихотэ-Алиньского орогенного пояса // Там же. 2020. Т. 39, № 3. C. 51-67. DOI: 10.30911/0207-4028-2020-39-3-51-67
Мишин Л. Ф., Чжсао Ч., Солдатов А. И. Мезозойскокайнозойские вулкано-плутонические пояса и системы в континентальной части Востока Азии и их зональность // Тихоокеанская геология. 2003. Т. 22, № 3. С. 28-47.

Печерский Д. М. Магнитные свойства гранитоидов северо-востока СССР // Тр. СВКНИИ. Магадан, 1964. Вып. 9. С. 6-158.

Романовский Н. П. Петрофизика гранитоидных рудно-магматических систем Тихоокеанского пояса. Москва : Наука, 1987. 192 с.

Соболев Н. В., Добрецов Н. Л., Отани Э., Тэйлор Л. А., Шертл Г.-П., Пальянов Ю. Н., Литасов К. Д. Проблемы, связанные с кристаллогенезисом и глубинным циклом углерода // Геология и геофизика. 2015. Т. 56, № 1-2. С. 5-20. DOI: 10.15372/ GiG20150101

Ханчук А. И., Гребенников А. В., Иванов В. В. Альбсеноманские окраинно-континентальный орогенный пояс и магматическая провинция Тихоокеанской Азии // Тихоокеанская геология. 2019. Т. 38, № 3. C. 4-37. DOI: 10.30911/0207-4028-2018-38-3-4-37

DeCelles P. G. Late Jurassic to Eocene evolution of the Cordilleran thrust belt and foreland basin system, western U. S. A. // American Journal of Science. 2004. 304. P. 105-168.

Deschamps F., Godard M., Guillot S., Hattori K. Geochemistry of subduction zone serpentinites: A review // Lithos. 2013. 178. P. 96-127. http://dx.doi.org/10.1016/j. lithos.2013.05.019

Dmitrienko L. V., Wang P., Li S., Cao X., Somerville I., Zhou Z., Hu M., Suo Y., Guo L., Wang Y., Li X., Liu X., Yu S., Zhu J. Meso-Cenozoic Evolution of Earth Surface System under the East Asian Tectonic Superconvergence // Acta Geologica Sinica. 2018.Vol. 92, No. 2. P. 814-849. DOI: $10.1111 / 1755-6724.13556$

Evans K. A., Reddy S. M., Tomkins A. G., Crossley R. J., Frost B. R. Effects of geodynamic setting on the redox state of fluids released by subducted mantle lithosphere // Lithos. 2017. 278-281. P. 26-42. http://dx.doi. org/10.1016/j.lithos.2016.12.023

Grebennikov A. V., Khanchuk A. I., Gonevchuk V. G., Kovalenko $S$. $V$. Cretaceous and Paleogene granitoid suites of the Sikhote-Alinarea (Far East Russia): Geochemistry and tectonic implications // Lithos. 2016. 261. P. 250-261 http://dx.doi.org/10.1016/j.lithos.2015.12.020

Guo N.-X., Zhao Z., Gao J.-F., Chen W., Wang D.-H., Chen Y.-C. Magmatic evolution and W-Sn-U-Nb-Ta mineralization of the Mesozoic Jiulongnao granitic complex, Nanling Range, South China // Ore Geology Reviews. 2018. 94. P. 414-434. https://doi.org/10.1016/j. oregeorev.2018.02.01

Gutscher M.-A. Scraped by fat-slab subduction // Nature Geoscience. 2018. 11. P. 889-893. https://doi. org/10.1038/s41561-018-0270-x

Hart C. J. R., Goldfarb R. J., Lewis L. L., Mair J. L. The Northern Cordilleran Mid-Cretaceous Plutonic Province: Ilmenite/Magnetite-series Granitoids and Intrusion-related Mineralisation // Resource Geology. 2004. Vol. 54, No. 3. P. 253-280. 
Hong L., Xu Y., Zhang L., Liu Z., Xia X., Kuang Y. Oxidized Late Mesozoic subcontinental lithospheric mantle beneath the eastern North China Craton: A clue to understanding cratonic destruction // Gondwana Research. 2020. 81. P. 230-239. https://doi.org/10.1016/j. gr.2019.11.012

Ishihara $S$. The magnetite-series and ilmenite-series granite rocks // Mining Geology. 1977. Vol. 27. P. 293305.

Ishihara S. Granitoid Series and Mineralization in the Circum-Pacific Phanerozoic Granitic Belts // Resource Geology. 1998. Vol. 48, No. 4. P. 219-224.

Kaminsky F. $V$. Water in the Earth's Lower Mantle // Geochemistry International. 2018. Vol. 56, No. 12. P. 1117-1134. DOI: 10.1134/S0016702918120042

Kemkin I. V., Khanchuk A. I., Kemkina R. A. Accretionary prisms of the Sikhote-Alin Orogenic Belt: Composition, structure and significance for reconstruction of the geodynamic evolution of the eastern Asian margin // Journal of Geodynamics. 2016. 102. P. 202-230. http:// dx.doi.org/10.1016/j.jog.2016.10.002

Khanchuk A. I., Kemkin I. V., Krukc N. N. The Sikhote-Alin orogenic belt, Russian South East: Terranes and the formation of continental lithosphere based on geological and isotopic data // Journal of Asian Earth Sciences. 2016. 120. P. 117-138. doi.org/10.1016/j. jseaes.2015.10.023

Kuritani T., Xia Q.-K., Kimura J.-I., Liu J., Shimizu K., Ushikubo T., Zhao D., Nakagawa M., Yoshimura S. Buoyant hydrous mantle plume from the mantle transition zone // Scientific Reports. 2019. 9. https://doi.org/10.1038/ s41598-019-43103-y

Lei J. Upper-mantle tomography and dynamics beneath the North China Craton // Journal of Geophysical Research: Solid Earth. 2012. 117. B06313. doi:10.1029/2012JB009212

Lei J., Xie F., Fan Q. Santosh M. Seismic imaging of the deep structure under the Chinese volcanoes: An overview // Physics of the Earth and Planetary Interiors. 2013. 224. P. 104-123. http://dx.doi.org/10.1016/j. pepi.2013.08.008

Li W., Yang Z., Chiaradia M., Lai Y., Yu C., Zhang J. Redox state of southern Tibetan upper mantle and ultrapotassic magmas // Geology. 2020. No. 48. https://doi. org/10.1130/G47411.1

Linnen R. L., Pichavant M., Holtz F., Burgess S. The effect of $\mathrm{fO}_{2}$ on the solubility, diffusion, and speciation of tin in haplogranitic melt at $850^{\circ} \mathrm{C}$ and $2 \mathrm{kbar} / / \mathrm{Geo}-$ chimica et Cosmochimica Acta. 1995. Vol. 59, No. 8. P. 1579-1588.

Malaspina N., Langenhorst F., Tumiati S., Campione M., Frezzotti M. L., Poli S. The redox budget of crust-derived fluid phases at the slab-mantle interface // Geochimica et Cosmochimica Acta. 2017. 209. P. 70-84. https:// doi.org/10.1016/j.gca.2017.04.004

Meer D. G., Hinsbergen D. J. J., Spakman W. Atlas of the underworld: Slab remnants in the mantle, their sink- ing history, and a new outlook on lower mantle viscosity // Tectonophysics. 2018. 723. P. 309-448. https://doi. org/10.1016/j.tecto.2017.10.004

Merkulova M. V., Muñoz M., Brunet F., Vidal O., Hattori K., Vantelon D., Trcera N., Huthwelker T. Experimental insight into redox transfer by iron- and sulfur-bearing serpentinite dehydration in subduction zones // Earth and Planetary Science Letters. 2017. 479. P. 133-143. http:// dx.doi.org/10.1016/j.eps1.2017.09.009

Monger J. W. H., Gibson H. D. Mesozoic-Cenozoic deformation in the Canadian Cordillera: The record of a "Continental Bulldozer"? // Tectonophysics. 2019. 757. P. 153-169. https://doi.org/10.1016/j. tecto.2018.12.023

Romer R. L., Kroner U. Phanerozoic tin and tungsten mineralization-Tectonic controls on the distribution of enriched protoliths and heat sources for crustal melting // Gondwana Research. 2016. 31. P. 60-95. http://dx.doi. org/10.1016/j.gr.2015.11.002.

Sato $K$. Sedimentary Crust and Metallogeny of Granitoid Affinity: Implications from the Geotectonic Histories of the Circum-Japan Sea Region, Central Andes and Southeastern Australia // Resource Geology. 2012. Vol. 62, No. 4. P. 329-351. https://doi.org/10.1111/ j.1751-3928.2012.00200.x

Seton M., Müller R. D., Zahirovic S., Gaina C., Torsvik T., Shephard G., Talsma A., Gurnis M., Turner M., Maush S., Chandler M. Global continental and ocean basin reconstructions since $200 \mathrm{Ma} / /$ Earth-Science Reviews. 2012. 113. P. 212-270. doi:10.1016/j. earscirev.2012.03.002

Sun M., Chen H., Milan L. A., Wilde S. A., Jourdan F., $X u Y$. Continental arc and back-arc migration in eastern NE China: New constraints on Cretaceous Paleo-Pacific subduction and rollback // Tectonics. 2018. 37. P. 3893 3915. doi.org/10.1029/2018TC005170

Tang J., Xu W., Wang F., Ge W. Subduction history of the Paleo-Pacific slab beneath Eurasian continent: Mesozoic-Paleogene magmatic records in Northeast Asia // Science China Earth Sciences. 2018. 61. P. 527-559. https:// doi.org/10.1007/s11430-017-9174-1

Wang Z., Kusky T. M., Capitanio F. A. Water transportation ability of flat-lying slabs in the mantle transition zone and implications for craton destruction // Tectonophysics. 2018. 723. P. 95-106. https://doi.org/10.1016/j. tecto.2017.11.041

Wang Z.-Z., Liu J., Xia Q.-K., Hao Y.-T., Wang Q.-Y. The distribution of water in the early Cretaceous lithospheric mantle of the North China Craton and implications for its destruction // Lithos. 2020. P. 360-361. https://doi. org/10.1016/j.lithos.2020.105412

Wendt A. S., Vaughan A. P. M., Ferraccioli F., Grunow A. M. Magnetic susceptibilities of rocks of the Antarctic Peninsula: Implications for the redox state of the batholith and the extent of metamorphic zones // Tectonophysics. 2013. 585. P. 48-67. http://dx.doi.org/10.1016/j. tecto.2012.07.011 


\title{
REDOX BACKGROUND IN THE EARTH'S CRUST OF THE SIKHOTE-ALIN OROGENIC BELT IN CRYSTALLIZATION OF CRETACEOUS-PALEOGENE MAGMATITES: CONNECTION WITH GEODYNAMICS
}

\author{
Yu. V. Taltykin, L. F. Mishin, E. A. Konovalova
}

Yu. A. Kosygin Institute of Tectonics and Geophysics, FEB RAS, Khabarovsk

\begin{abstract}
A new mechanism for the formation of ilmenite and magnetite series of granitoids in the Sikhote-Alin orogenic belt is proposed. The existing distribution zones of these magmatites are associated with the regional redox background, where magma crystallization occurs. The paper shows the relationship between the redox background in the lithosphere of the region and subduction processes in the Cretaceous-Paleogene time. The proposed mechanism of formation of the ilmenite and magnetite zones of Sikhote-Alin also explains the differences in redox conditions during the crystallization of Mesozoic magmatites in the orogens of the Eastern and Western Pacific coasts.
\end{abstract}

Keywords: magnetite series, ilmenite series, granites, slab, redox conditions, redox background, Sikhote-Alin, Pacific Belt.

\section{REFERENCES}

Argentov, V. V., Gnibidenko, G. S., Popov, A. A., Potapev, S. V., 1976. Deep Structure of Primorye (According to the DSS Data). Moscow, Nauka [In Russian].

Bakharev, A. G., Shkodzinskiy, V. S., Zhdanov, Yu. Ya., 2005. Graphite-Containing Acidic Igneous Rocks of the Tas-Kystabyt Magmatic Belt of the Verkhoyansk-Kolyma Folded Region, Otechestvennaya Geologiya. 5, 54-57 [In Russian].

Borisov, A. A., Zharkova, E. V., Kadik, A. A., Kravchuk, I. F., Lukanin, O. A., Malinin, S. D., Shilobreeva S. N., 1991. Fluids and Redox Equilibria in Magmatic Systems. Moscow, Nauka [In Russian].

DeCelles, P. G., 2004. Late Jurassic to Eocene Evolution of the Cordilleran Thrust Belt and Foreland Basin System, Western U. S. A., American Journal of Science. 304, 105-168.

Deschamps, F., Godard, M., Guillot, S., Hattori, K., 2013. Geochemistry of Subduction Zone Serpentinites: A Review, Lithos. 178, 96-127. http://dx.doi.org/10.1016/j. lithos.2013.05.019

Didenko, A. N., Khanchuk, A. I., 2019. Change of Geodynamic Settings in the Transition Zone of the Pacific Ocean - Eurasia at the End of the Early Cretaceous, Doklady Akademiyi Nauk. 487, 4, 186-191. DOI: https:// doi.org/10.31857/S0869-56524874405-408 [In Russian].

Dmitrienko, L. V., Wang, P., Li, S., Cao, X., Somerville, I., Zhou, Z., Hu, M., Suo, Y., Guo, L.,Wang, Y., Li, X., Liu, X., Yu, S., Zhu, J., 2018. Meso-Cenozoic Evolution of Earth Surface System under the East Asian Tectonic Superconvergence, Acta Geologica Sinica. 92, 2, 814 849. DOI: $10.1111 / 1755-6724.13556$

Dobretsov, N. L., Kulakov, I. Yu., Litasov, K. D., Kukarina, E. V., 2015. Significance of Geology, Experimental Petrology and Seismotomography for Comprehensive Assessment of Subduction Processes,
Russian Geology and Geophysics. 56, 1-2, 21-55. DOI: 10.15372/GiG20150102 [In Russian].

Dobretsov, N. L., Simonov, V. A., Kulakov, I. Yu., Kotlyarov, A.V., 2017. Problems of Fluids and Melt Filtration in Subduction Zones and General Issues of Thermal Modeling in Geology, Russian Geology and Geophysics. 58, 5, 701-722. DOI: 10.15372/GiG20170503 [In Russian].

Evans, K. A., Reddy, S. M., Tomkins, A. G., Crossley, R. J., Frost, B. R., 2017. Effects of Geodynamic Setting on the Redox State of Fluids Released by Subducted Mantle Lithosphere, Lithos. 278-281, 26-42. http:// dx.doi.org/10.1016/j.lithos.2016.12.023

Grebennikov, A. V., Khanchuk, A. I., Gonevchuk, V. G., Kovalenko, S. V., 2016. Cretaceous and Paleogene Granitoid Suites of the Sikhote-Alin area(Far East Russia): Geochemistry and Tectonic Implications, Lithos. 261, 250-261. http://dx.doi.org/10.1016/j.lithos.2015.12.020

Guo, N.-X., Zhao, Z., Gao, J.-F., Chen, W., Wang, D.-H., Chen, Y.-C., 2018. Magmatic Evolution and W $\mathrm{Sn}-\mathrm{U}-\mathrm{Nb}$ - Ta Mineralization of the Mesozoic Jiulongnao Granitic Complex, Nanling Range, South China, Ore Geology Reviews. 94, 414-434. https://doi. org/10.1016/j.oregeorev.2018.02.01

Gutscher, M.-A., 2018. Scraped by Fat-Slab Subduction, Nature Geoscience. 11, 889-893. https://doi. org/10.1038/s41561-018-0270-x

Hart, C. J. R., Goldfarb, R. J., Lewis, L. L., Mair, J. L., 2004. The Northern Cordilleran Mid-Cretaceous Plutonic Province: Ilmenite/Magnetite-Series Granitoids and Intrusion-Related Mineralisation, Resource Geology. 54, 3, 253-280.

Hong, L., Xu, Y., Zhang, L., Liu, Z., Xia, X., Kuang, Y., 2020. Oxidized Late Mesozoic Subcontinental Lithospheric Mantle Beneath the Eastern North China 
Craton: A Clue to Understanding Cratonic Destruction, Gondwana Research. 81, 230-239. https://doi. org/10.1016/j.gr.2019.11.012

Ishihara, S., 1977. The Magnetite-Series and IlmeniteSeries Granite Rocks, Mining Geology. 27, 293-305.

Ishihara, S., 1998. Granitoid Series and Mineralization in the Circum-Pacific Phanerozoic Granitic Belts, Resource Geology. 48, 4, 219-224.

Kadik, A. A., 2003. Restored Mantle Fluids: Connection with Chemical Differentiation of Planetary Matter, Geochemistry International. 9, 928-940 [In Russian].

Kadik, A. A., Lukanin, O. A., 1986. Degassing of the Upper Mantle during Melting. Moscow, Nauka [In Russian].

Kaminsky, F. V., 2018. Water in the Earth's Lower Mantle, Geochemistry International. 56 (12), 1117-1134. DOI: $10.1134 / \mathrm{S} 0016702918120042$

Kemkin, I. V., Khanchuk, A. I., Kemkina, R. A., 2016. Accretionary Prisms of the Sikhote-Alin Orogenic Belt: Composition, Structure and Significance for Reconstruction of the Geodynamic Evolution of the Eastern Asian Margin, Journal of Geodynamics. 102, 202-230. http://dx.doi.org/10.1016/j.jog.2016.10.002

Khanchuk, A. I., Grebennikov, A. V., Ivanov, V. V., 2019. Albian-Cenomanian Marginal-Continental Orogenic Belt and Magmatic Province of Asia Pacific, Tikhookeanskaya Geologiya. 38 (3), 4-37. DOI: 10.30911/0207-4028-2018-38-3-4-37 [In Russian].

Khanchuk, A. I., Kemkin, I. V., Kruk, N. N., 2016. The Sikhote-Alin Orogenic Belt, Russian South East: Terranes and the Formation of Continental Lithosphere Based on Geological and Isotopic Data, Journal of Asian Earth Sciences. 120, 117-138. doi.org/10.1016/j. jseaes.2015.10.023

Kuritani, T., Xia, Q.-K., Kimura, J.-I., Liu, J., Shimizu, K., Ushikubo, T., Zhao, D., Nakagawa, M., Yoshimura, S., 2019. Buoyant Hydrous Mantle Plume from the Mantle Transition Zone, Scientific Reports. 9. https://doi. org/10.1038/s41598-019-43103-y

Lei, J., 2012. Upper-Mantle Tomography and Dynamics Beneath the North China Craton, Journal of Geophysical Research: Solid Earth. 117, B06313. DOI: $10.1029 / 2012 J B 009212$

Lei, J., Xie, F., Fan, Q., 2013. Santosh M. Seismic Imaging of the Deep Structure under the Chinese Volcanoes: An Overview, Physics of the Earth and Planetary Interiors. 224, 104-123. http://dx.doi. org/10.1016/j.pepi.2013.08.008

Letnikov, F. A., 2006. Ultra-Deep Fluid Systems of the Earth. http://csr.spbu.ru/pub/RFBR_publications/articles/ geosciences/2006/sverhglubinnie flyuidnie sistemi Zemli_06_geo.pdf [In Russian]

Li, W., Yang, Z., Chiaradia, M., Lai, Y., Yu., C., Zhang, J., 2020. Redox State of Southern Tibetan Upper Mantle and Ultrapotassic Magmas, Geology. 48. https://doi. org/10.1130/G47411.1

Linnen, R. L., Pichavant, M., Holtz, F., Burgess, S., 1995. The Effect of $\mathrm{fO}_{2}$ on the Solubility, Diffusion, and Speciation of Tin in Haplogranitic Melt at $850^{\circ} \mathrm{C}$ and 2 kbar, Geochimica et Cosmochimica Acta. 59 (8), 1579-1588.

Malaspina, N., Langenhorst, F., Tumiati, S., Campione, M., Frezzotti, M. L., Poli, S., 2017. The Redox Budget of Crust-Derived Fluid Phases at the Slab-Mantle Interface, Ibid. 209, 70-84. https://doi.org/10.1016/j. gca.2017.04.004
Meer, D. G., Hinsbergen, D. J. J., Spakman, W., 2018. Atlas of the Underworld: Slab Remnants in the Mantle, Their Sinking History, and a New Outlook on Lower Mantle Viscosity, Tectonophysics. 723, 309-448. https:// doi.org/10.1016/j.tecto.2017.10.004

Merkulova, T. V., Mishin, L. F., 2015. Redox Processes in Mesozoic-Cenozoic Volcano-Plutonic Systems and Their Role in the Formation of Regional Gravitational and Magnetic Anomalies of the Far East, Tikhookeanskaya Geologiya. 34, 6, 112-124 [In Russian].

Merkulova, M. V., Muñoz, M., Brunet, F., Vidal, O., Hattori, K., Vantelon, D., Trcera, N., Huthwelker, T., 2017. Experimental Insight Into Redox Transfer by Iron- and Sulfur-Bearing Serpentinite Dehydration in Subduction Zones, Earth and Planetary Science Letters. 479, 133 143. http://dx.doi.org/10.1016/j.eps1.2017.09.009

Mishin, L. F., 2010. Eu Geochemistry in Magmatic Rocks of Continental Marginal Volcanic Belts, Geochemistry International. 6, 618-631. DOI: 10.1134/ S0016702910060054 [In Russian].

Mishin, L. F., Kirillova, G. L., Merkulova, T. V., Konovalova, E. A., 2019. Redox Conditions for the Formation of Post-Collisional Magmatism and Metallogeny of the Western Sector of the Mongol-Okhotsk Orogenic Belt, Tikhookeanskaya Geologiya. 38, 4, 3-12. DOI: 10.30911/0207-4028-2019-38-4-3-12 [In Russian]. Mishin, L. F., Konovalova, E. A., Taltykin, Yu. V., Krutikova, V. O., Dobkin, S. N., Yurchenko, Yu. Yu., Shtareva, A.V., 2020. Oxidative Conditions and Associated Geochemical and Metallogenic Zonality in Magmatic Formations of the Sikhote-Alin Orogenic Belt, Ibid. 39, 3, 51-67. DOI: 10.30911/0207-4028-2020-39-3-51-67 [In Russian].

Mishin, L. F., Zhao, Ch., Soldatov, A. I., 2003. Mesozoic-Cenozoic Volcano-Plutonic Belts and Systems in the Continental Part of East Asia and Their Zoning, Tikhookeanskaya Geologiya. 22, 3, 28-47 [In Russian].

Monger, J. W. H., Gibson, H. D., 2019. MesozoicCenozoic Deformation in the Canadian Cordillera: The Record of a "Continental Bulldozer"?, Tectonophysics. 757, 153-169. https://doi.org/10.1016/j.tecto.2018.12.023

Pechersky, D. M., 1964. Magnetic Properties of Granitoids in the North-East of the USSR, Trudy SVKNII. Magadan. 9, 6-158 [In Russian].

Romanovsky, N. P., 1987. Petrophysics of Granitoid Ore-Magmatic Systems of the Pacific Belt. Moscow, Nauka [In Russian].

Rome, R. L., Kroner, U., 2016. Phanerozoic Tin and Tungsten Mineralization - Tectonic Controls on the Distribution of Enriched Protoliths and Heat Sources for Crustal Melting, Gondwana Research. 31, 60-95. http:// dx.doi.org/10.1016/j.gr.2015.11.002.

Sato, K., 2012. Sedimentary Crust and Metallogeny of Granitoid Affinity: Implications from the Geotectonic Histories of the Circum-Japan Sea Region, Central Andes and Southeastern Australia, Resource Geology. 62 (4), 329351. https://doi.org/10.1111/j.1751-3928.2012.00200.x

Seton, M., Müller, R. D., Zahirovic, S., Gaina, C., Torsvik, T., Shephard, G., Talsma, A., Gurnis, M., Turner, M., Maush, S., Chandler, M., 2012. Global Continental and Ocean Basin Reconstructions Since $200 \mathrm{Ma}$, Earth-Science Reviews. 113, 212-270. doi:10.1016/j. earscirev.2012.03.002 
Sobolev, N. V., Dobretsov, N. L., Otani, E., Tailor, L. A., Sheertle, G.-P., Paliyanov, Yu. N., Litasov, K. D., 2015. Problems Related to Crystal Genesis and a Deep Carbon Cycle, Russian Geology and Geophysics. 56 (1-2), 5-20. DOI: 10.15372/GiG20150101 [In Russian].

Sun, M., Chen, H., Milan, L. A., Wilde, S. A., Jourdan, F., $X u, Y$., 2018. Continental Arc and Back-Arc Migration in Eastern NE China: New Constraints on Cretaceous Paleo-Pacific Subduction and Rollback, Tectonics. 37, 3893-3915. DOI.org/10.1029/2018TC005170

Tang, J., Xu, W., Wang, F., Ge, W., 2018. Subduction History of the Paleo-Pacific Slab Beneath Eurasian Continent: Mesozoic-Paleogene Magmatic Records in Northeast Asia, Science China Earth Sciences. 61, 527-559. https://doi.org/10.1007/s11430-017-9174-1
Wang, Z., Kusky, T. M., Capitanio, F. A., 2018. Water Transportation Ability of Flat-Lying Slabs in the Mantle Transition Zone and Implications for Craton Destruction, Tectonophys. 723, 95-106. https://doi.org/10.1016/j. tecto.2017.11.041

Wang, Z.-Z., Liu, J., Xia, Q.-K., Hao, Y.-T., Wang, Q.-Y., 2020. The Distribution of Water in the Early Cretaceous Lithospheric Mantle of the North China Craton and Implications for Its Destruction, Lithos. 360-361. https://doi.org/10.1016/j.lithos.020. 105412

Wendt, A. S., Vaughan, A. P. M., Ferraccioli, F., Grunow, A. M., 2013. Magnetic Susceptibilities of Rocks of the Antarctic Peninsula: Implications for the Redox State of the Batholith and the Extent of Metamorphic Zones, Tectonophysics. 585, 48-67. http://dx.doi.org/10.1016/j.tecto.2012.07.011 